\title{
Inhibition of p38MAP kinase suppresses fibrotic reaction of retinal pigment epithelial cells
}

Shizuya Saika ${ }^{1}$, Osamu Yamanaka ${ }^{1}$, Kazuo Ikeda ${ }^{2}$, Shokei Kim-Mitsuyama ${ }^{3}$, Kathleen C Flanders ${ }^{4}$, Jiyun Yoo $^{4, *}$, Anita B Roberts ${ }^{4}$, Iku Nishikawa-Ishida ${ }^{1}$, Yoshitaka Ohnishi $^{1}$, Yasuteru Muragaki ${ }^{5}$ and Akira Ooshima ${ }^{5}$

${ }^{1}$ Department of Ophthalmology, Wakayama Medical University, Kimiidera, Wakayama, Japan; ${ }^{2}$ Department of Anatomy, Graduate School of Medicine, Osaka City University, Asahimachi, Abeno, Osaka, Japan; ${ }^{3}$ Department of Pharmacology and Molecular Therapeutics, Kumamoto University Graduate School of Medical Science, Kumamoto, Japan; ${ }^{4}$ Laboratory of Cell Regulation and Carcinogenesis, National Cancer Institute, National Institutes of Health, Bethesda, MD, USA and ${ }^{5}$ Department of Pathology, Wakayama Medical University, Kimiidera, Wakayama, Japan

\begin{abstract}
Proliferative vitreoretinopathy (PVR) is one of the major causes of the failure of retinal detachment surgery. Its pathogenesis includes a fibrotic reaction by the retinal pigment epithelium and other retina-derived non-neural cells, leading to fixation of the detached retina. We examined the role of p38 mitogen-activated protein kinase (MAPK) in transforming growth factor (TGF)- 32 -dependent enhancement of the fibrogenic reaction in a human retinal pigment epithelial cell line, ARPE-19, and also evaluated the therapeutic efficacy of inhibiting p38MAPK by adenoviral gene transfer of dominant-negative (DN) p38MAPK in a mouse model of PVR. Exogenous TGF- $\beta 2$ activates p38MAPK in ARPE-19 cells. It also suppresses cell proliferation, but this was unaffected by addition of the p38MAPK inhibitor, SB202190. SB202190 interfered with TGF- $\beta 2$-dependent cell migration and production of collagen type I and fibronectin, but had no effect on basal levels of these activities. While SB202190 did not affect phosphorylation of the C-terminus of Smads2/3, it did suppress the transcriptional activity of Smads3/4 as indicated by a reporter gene, CAGA12-Luc. Gene transfer of DN-p38MAPK attenuated the post-retinal detachment fibrotic reaction of the retinal pigment epithelium in vivo in mice, supporting its effectiveness in preventing/treating PVR.
\end{abstract}

Laboratory Investigation (2005) 85, 838-850. doi:10.1038/labinvest.3700294; Published online 16 May 2005

Keywords: proliferative vitreoretinopathy; gene therapy; adenovirus; retinal pigment epithelial cell; transforming growth factor $\beta$; p38 mitogen-activated kinase

Retinal pigment epithelial cells (RPE cells) are disseminated in the subretinal space and also vitreous humor, and then settle on the retinal surface during intervals following development of rhegmatogenous retinal detachment. ${ }^{1,2}$ RPE cells then undergo transformation to fibroblast-like cells, proliferate and produce extracellular matrix (ECM) components, participating in the formation of

Correspondence: Dr S Saika, MD, PhD, Department of Ophthalmology, Wakayama Medical University, 811-1 Kimiidera, Wakayama 641-0012, Japan.

E-mail: shizuya@wakayama-med.ac.jp

${ }^{*}$ Current address: Department of Microbiology/Research Institute of Life Science, Gyeongsang National University, Jinju 660-701, Korea.

Received 28 February 2005; revised and accepted 11 April 2005; published online 16 May 2005 fibrotic tissue on the detached retina (proliferative vitreoretinopathy, PVR). ${ }^{1-3}$ These fibrotic sequelae reduce the flexibility of the retina and may potentially make it difficult to reattach the retina.

Transforming growth factor $\beta$ (TGF- $\beta$ ) is likely a key player in the development of PVR, although various other growth factors, including plateletderived growth factor, hepatocyte growth factor, and activin, are all reportedly involved in its pathogenesis. ${ }^{4-11}$ We have previously reported that increases in the concentration of TGF- $\beta 2$ in the vitreous humor of the eye correlate with the severity of the PVR, supporting the importance of this factor. ${ }^{12}$ It is also well documented that TGF- $\beta$ can induce transformation of RPE to fibroblast-like cells in vitro. ${ }^{13-15}$ We have recently shown that signaling through Smad3, a key mediator of signals from the 
TGF- $\beta$ and activin receptors, is required for the development of PVR-like lesion in a mouse eye following induction of retinal detachment (Saika $S$ et al, press). However, TGF- $\beta$ can also activate other, non-Smad signaling cascades, including especially the mitogen-activated protein kinase (MAPK) pathways leading to activation of MAPK-Erk, Jun Nterminal kinase (JNK), and p38MAPK. ${ }^{16,17}$ These pathways frequently cooperate with the Smad signaling pathway in mediating responses of TGF$\beta$ on cells. It has been recently reported that such phosphorylation by MAP kinases in the Smad3 linker region is required for the full activation of Smad signaling. ${ }^{18,19}$ Moreover, it has been reported that members of the AP-1 complex, activated by the JNK pathway and commonly involved in upregulation of expression of ECM proteins, are upregulated in RPEs in vivo following experimental retinal detachment. $^{20}$

p38MAPK has been implicated in TGF- $\beta$ mediated fibroblastic transdifferentiation and cell migration in cultured tumor-derived and non-tumorderived mammary epithelial cells. ${ }^{21-27}$ We and others have also recently reported that the TGF- $\beta 2$ / p38MAPK cascade, which is activated in mouse corneal epithelium upon epithelial debridement, is needed for epithelial cell migration and cessation of cell proliferation. ${ }^{28,29}$ In mesenchymal cells, p38MAPK is involved in expression of ECM molecules, that is, collagen or fibronectin and cell proliferation. ${ }^{30,31}$ While not yet proven, these observations suggest that the p38MAPK pathway might be involved in the pathogenesis of tissue fibrosis, as in PVR.

In the present study, we examined the role of TGF$\beta 2-\mathrm{p} 38 \mathrm{MAPK}$ signaling in regulation of the behavior of ARPE-19 cells, ${ }^{32}$ a human RPE cell line, by using a specific inhibitor of p38MAPK (SB202190) to address the role of this cascade in the pathogenesis of PVR. We then examined the effects of adenoviral gene transfer of dominant negative (DN)-p38MAPK to a mouse model of PVR. Since a single administration of the chemical p38MAPK inhibitor in vivo might lose its inhibitory effect due to a short half-life in tissue, we inhibited p38MAPK by viral gene expression of DN p38MAPK. We show here that signaling via p38MAPK is involved in the TGF- $\beta 2$ mediated promotion of cell migration and production of collagen type I and fibronectin in ARPE-19 cells and that DN-p38MAPK suppresses the fibrotic reaction of retinal pigment epithelial cells a mouse model of PVR.

\section{Materials and methods}

\section{Cell Culture}

ARPE-19 cells ${ }^{32}$ were obtained from American Type Cell Culture (ATCC) and maintained in DMEM/F-12 medium (a mixture of Dulbecco's modified Eagle's minimun essential medium and Hank's Balanced salt solution) supplemented with $15 \%$ fetal calf serum (Gibco-BRL, Invitrogen, Grand Island, NY, USA) and antibiotics (Penicilline-streptomycin solution, Gibco-BRL).

\section{TGF- $\beta 2$ Activation of p38MAPK}

\section{Immunocytochemical analysis}

ARPE-19 cells were seeded in the wells of a chamber slides (Nunc, Naperville, IL, USA) and cultured in DMEM/F-12 supplemented with $15 \%$ fetal calf serum. Subconfluent cells were then treated with TGF- $\beta 2(1.0 \mathrm{ng} / \mathrm{ml}$, R\&D System, Minneapolis, MN, USA) for specific intervals and fixed in $4.0 \%$ paraformaldehyde. The specimens were then processed for immunofluorescence staining with a monoclonal anti-phosphorylated p38MAPK antibody ([1:50 dilution in phosphate-buffered saline (PBS), Cell Signaling Technology, Beverly, MA, USA) as previously reported. ${ }^{26}$ Negative control staining was performed by using nonspecific mouse IgG.

\section{Quantification of activation of p38MAPK}

Total and phosphorylated p38MAPK in the cells were quanitified by using a enzyme-linked immunosorbent assay (ELISA) kit $\left(\mathrm{FACE}^{\mathrm{TM}}\right.$ p38 ELISA lit, Active Motif Carlsbad, CA, USA). Cells were seeded in 96-well culture plates. While still subconfluent, the cells were treated with TGF- $\beta 2(1.0 \mathrm{ng} / \mathrm{ml})$ for specific intervals and fixed in $4.0 \%$ paraformaldehyde. Eight wells were prepared for each culture condition. Specimens were then processed for immunocytochemical detection of total and phosphorylated p38MAPK by using antibodies supplied in the kit. After reaction with the primary and then secondary antibodies, the color reaction was performed by the substrate also contained in the kit. Absorbance at $450 \mathrm{~nm}$ was determined by a microplate reader BioRad model 550.

\section{Cell proliferation assay by MTT method}

MTT assay (TACS MTT Cell Proliferation Assay Kit, Trevigen, Gaithersburg, MD, USA) is well established to determine the cell growth and is correlated to the total cell number. ARPE-19 cells were seeded in the wells of a 96-well plate $\left(2 \times 10^{4} / 100 \mu \mathrm{l} /\right.$ well $)$ and were allowed to grow for $12 \mathrm{~h}$. The cells were then treated with test serum-free culture medium supplemented with SB202190 (10 $\mu \mathrm{M}$, Calbiochem), TGF- $\beta 2 \quad(1.0 \mathrm{ng} / \mathrm{ml}), \quad$ TGF- $\beta 2 \quad(1.0 \mathrm{ng} / \mathrm{ml})$ plus SB202190 $(10 \mu \mathrm{M} / \mathrm{ml})$ and further incubated for $24 \mathrm{~h}$. All the cultures contained the same concentration of dimethylsulfoxide (DMSO). Proliferation of ARPE-19 cells was assessed using the MTT assay according to the manufacturer's instructions. At the end of each culture interval, MTT reagent $(10 \mu \mathrm{l})$ was added to each well and further incubated for $5 \mathrm{~h}$ at $37^{\circ} \mathrm{C}$ Optical density at $570 \mathrm{~nm}$ was measured $4 \mathrm{~h}$ after adding the lysis solution contained in the kit. 
To confirm that the cells are responsive to growth factors, we determined with the MTT assay whether epidermal growth factor ( $10 \mathrm{ng} / \mathrm{ml}, \mathrm{R} \& \mathrm{D}$ Systems) can stimulate cell proliferation.

\section{ECM production}

Production of collagen type I and fibronectin, the major ECM components of PVR tissue, were assayed. ARPE-19 cells were grown to confluency in a six-well culture plate in DMEM/F-12 supplemented with $15 \%$ fetal calf serum and then further incubated in $500 \mu \mathrm{l}$ serum-free medium supplemented with SB202190 $(10 \mu \mathrm{M} / \mathrm{ml})$, TGF- $\beta 2(1.0 \mathrm{ng} / \mathrm{ml})$, TGF- $\beta 2(1.0 \mathrm{ng} / \mathrm{ml})$ plus SB202190 $(10 \mu \mathrm{M} / \mathrm{ml})$ for $48 \mathrm{~h}$. All the cultures contained the same concentration of DMSO. Nine wells were prepared for each culture condition. At the end of the culture interval, the medium was harvested and cells were sonicated in $500 \mathrm{ml}$ of PBS as previously reported. Medium and cell lysate were processed for ELISA kit for collagen type I C-terminal peptide and fibronectin (Takara, Tokyo, Japan) according to the protocol provided by the manufacturer. Color reaction was measured at $450 \mathrm{~nm}$.

Immunofluorecent cytochemistry was also carried out. Cells were grown to subconfluency in chamber slides (Nalge Nunc, Naperville, IL, USA) and then further incubated in each test medium same as above for $24 \mathrm{~h}$. The cells were fixed in $4.0 \%$ paraformaldehyde in $0.1 \mathrm{M}$ phosphate buffer. The cells were allowed to react with goat polyclonal anti-type I collagen antibody (1:100 dilution in PBS, Southern Biotechnology, Birmingham, AL, USA) or monoclonal anti-fibronectin antibody (1:100 dilution in PBS, Santa Cruz Biotechnology, Santa Cruz, CA, USA). After a wash in PBS, the specimens were treated with fluorescein-conjugated secondary antibodies and mounted in VectaShield H-1200 containing DAPI nuclear dye. Negative control was performed with non-immune IgG.

\section{Cell migration assay}

Cell migration was evaluated by assaying the closure of a liner defect produced in a cell monolayer culture as previously reported..$^{33} \mathrm{~A}$ defect was made in a confluent culture of ARPE-19 cells by scraping with a silicone rubber needle (Terry's needle, Alcon Surgical, Fort Worth, TX, USA). The culture was incubated in serum-free DMEM/F-12 in the presence of either SB202910 $(10 \mu \mathrm{M} / \mathrm{ml})$, TGF- $\beta 2(1.0 \mathrm{ng} / \mathrm{ml})$, TGF- $\beta 2(1.0 \mathrm{ng} / \mathrm{ml})$ plus SB202190 $(10 \mu \mathrm{M})$. Vehicleonly control cultures contained bovine serum albumin (BSA) at $1.0 \mathrm{ng} / \mathrm{ml}$ and all cultures were normalized to the same concentration of DMSO. After specific intervals of culture at 12, 24, 48 and $72 \mathrm{~h}$ post-wounding, the cells were fixed with $4 \%$ paraformaldehyde and processed for hematoxylin and eosin staining.

\section{Effect of the p38 Inhibitor on Smad Phosphorylation}

Cells were treated with SB202190 $(10 \mu \mathrm{M}$, Calbiochem) $1 \mathrm{~h}$ before addition of TGF- $\beta 2(1 \mathrm{ng} / \mathrm{ml})$. At different timepoints, cells were lysed in lysis buffer (25 mM HEPES, $150 \mathrm{mM} \mathrm{NaCl}, 10 \%$ glycerol, $5 \mathrm{mM}$ EDTA, 1\% Triton X-100, $5 \mathrm{mM}$ sodium orthovanadate, $50 \mathrm{mM} \mathrm{NaF}, 0.5 \mathrm{mg} / \mathrm{ml}$ AEBSF, $1 \mu \mathrm{g} / \mathrm{ml}$ pepstatin) and protein concentrations in cell lysates were determined by the BCA reagent (PIERCE, Rockford, IL, USA). For immunoblotting, whole-cell lysates were resolved on SDS-polyacrylamide gel electrophoresis and transferred to nitrocellulose membranes. The membranes were immunoblotted with antibodies against Smad2, Smad3, (both from Zymed, South San Francisco, CA, USA), phosphoSmad2 (Upstate Biotechnology, Lake Placid, NY, USA) and phospho-Smad3 (a gift from Dr Ed Leof), and the bound antibodies were visualized with horseradish peroxidase-conjugated antibodies to rabbit IgG using the enhanced chemiluminescence (ECL) Western blotting system (Amersham Pharmacia Biotech, Piscataway, NJ, USA). To assess effects of the p38 inhibitor on transcriptional activity of Smad3, cells seeded in six-well plates were transiently transfected with $4 \mu \mathrm{g} /$ well CAGA12-Luc, a reporter gene containing 12 repeats of the Smad binding element, CAGAC together with pRL-TK plasmid DNA using FuGene (Roche Diagnostics, Indianapolis, IN, USA) according to the manufacturer's instructions. pcDNA3 was used either as a control or as filler. At $24 \mathrm{~h}$ after transfection, the medium was replaced with medium containing $0.2 \%$ serum and cells were either treated with $2 \mathrm{ng} / \mathrm{ml}$ of TGF- $\beta 2$ or left untreated for $16-18 \mathrm{~h}$ and then were lysed in passive lysis buffer (Promega, Madison, WI, USA). Luciferase and renila activities were determined by VICTOR (Perkin-Elmer Life Sciences, Boston, MA, USA).

\section{Mouse PVR Model and Adenoviral Gene Introduction of DN-p38MAPK}

All experimental procedures were approved by the DNA Recombination Experiment Committee and Animal Care and Use Committee of Wakayama Medical University, Wakayama, Japan, and conducted in accordance with the Association for Research in Vision and Ophthalmology Statement for the Use of Animals in Ophthalmic and Vision Research.

The PVR model was used in a single eye of adult male C57BL/6 mice $(n=110)$ basically as described in our previous report. ${ }^{34}$ Briefly, under general anesthesia by pentobarbital sodium, i.p., a linear incision was made in the central cornea and the crystalline lens was removed. After the vitreous cavity was filled with $1.0 \%$ hyaluronan, the retina was gently removed with forceps without damaging the pigment epithelium. The exposed pigment epithelium was then scraped 5 times with a silicone 
rubber needle (Alcon Surgical, Inc., Fort Worth, TX, USA) and the corneal incision was sutured with 10-0 nylon string.

In all, $5 \mu \mathrm{l}$ of a solution of adenovirus $\left(1.0 \times 10^{7} \mathrm{PFU} / \mu \mathrm{l}\right)$ carrying either green fluorescein protein $(\mathrm{GFP})^{35,36}(n=15)$ or control LacZ (refered as LacZ-Ad) $(n=15)$ was administered to the vitreous cavity with a hypodermic needle introduced through the sutured corneal incision. LacZ-Ad was used to control for comparizon with GFP. At days 1, 2, 5, 10 and 20, unfixed cryosections of enucleated eyes were observed under fluorescence microscopy to examine the efficacy of gene introduction to the pigment epithelial cells.

Upon confirming that adenoviral genes were transferred to the retinal pigment epithelium in vivo by observing specimens treated with GFP-Ad, $5 \mu \mathrm{l}$ of solution of adenovirus $\left(1.0 \times 10^{7} \mathrm{PFU} / \mu \mathrm{l}\right)$ carrying either DN-p38MAPK cDNA $^{37}(n=40)$ or control vector (Lac-Ad) $(n=40)$ was administered to the vitreous cavity with a hypodermic needle introduced through the sutured corneal incision. At days $1,2,5,10$ or 20 post-treatment, the treated eyes were enucleated, fixed in $4.0 \%$ paraformaladehyde and embedded in paraffin $(n=6$ in each group at each timepoint) or processed for embedding in OCT compound ( $n=4$ in each group at each timepoint).

\section{Histology and Immunohistochemistry}

Deparaffinized sections ( $5 \mu \mathrm{m}$ ) of DN p38MAPK-Adtreated and Cre-Ad-treated eyes were processed for hematoxylin and eosin staining and indirect immunohistochemistry with either a mouse monoclonal anti- $\alpha$ SMA antibody (1:100 dilution in PBS, Neomarker, Fremont, CA, USA) or a goat polyclonal anti-type VI collagen antibody (1:100 in PBS, Southern Biotechnology, Birmingham AL, USA). Cryosections of these specimens were immunostained with anti-HA-Tag262 K antibody ${ }^{35}$ (1:100 dilution in PBS, Cell Signaling, Beverly, MA, USA) for detection of exogenous gene expression or mouse monoclonal antiphosphorylated p38MAPK antibody (1:100 dilution in PBS, Cell Signaling). FITC-conjugated secondary antibodies were used to visualize the specific immunoreaction as previously reported. ${ }^{34-36}$

\section{Results}

\section{Activation of p38MAPK}

In quiescent conditions in the absence of exogenous TGF- $\beta 2$ (Figure 1a, timepoint $0 \mathrm{~h}$ ), as well as $0.5 \mathrm{~h}$ after TGF- $\beta 2$ addition (Figure 1a, timepoint $0.5 \mathrm{~h}$ ), a low level of phosphorylated p38MAP is detected in the cytoplasm, but not in the nuclei of ARPE-19 cells. At $1 \mathrm{~h}$ after addition of TGF- $\beta 2$, phosphop38MAPK was upregulated in the cytoplasm and faint nuclear phospho-p38MAPK was also seen (Figure 1a, timepoint $1 \mathrm{~h}$ ). Marked nuclear phos-
pho-38MAPK was observed at 6 and $12 \mathrm{~h}$ post-TGF$\beta 2$ addition and this was no longer detectable by $24 \mathrm{~h}$ (Figure 1a). The results obtained by using ELISA assay of total and phosphorylated p38MAPK corroborated the immunocytochemical staining. The level of total p38MAPK never changed (Figure 1b), whereas that of phospho-p38MAPK was transiently upregulated with a peak at $6 \mathrm{~h}$ after addition of TGF- $\beta 2$ (Figure 1c).

\section{Cell Proliferation}

Addition of TGF- $\beta 2$ at $1.0 \mathrm{ng} / \mathrm{ml}$ to cells growing in serum-free medium inhibited the growth of the cells. Addition of SB202190 at $10 \mu \mathrm{M} / \mathrm{ml}$ had no effect on cell proliferation either in the presence or absence of TGF- $\beta 2$, suggesting that this pathway is not involved in the antiproliferative effects of TGF$\beta 2$ (Figure 2). The MTT assay showed that EGF at $10 \mathrm{ng} / \mathrm{ml}$ enhanced cell proliferation approximately about $125 \%$ above the control, indicating that this cell line is responsive to growth factor stimulation (data not shown).

\section{ECM Production}

SB202190 did not have any effect on production of collagen type I in ARPE-19 cell cultures in the absence of exogenous TGF- $\beta 2$ as shown by both immunocytochemistry and ELISA data. Immunocytochemistry showed increased deposition of collagen type I in cells treated with TGF- $\beta 2$ (Figure $3 \mathrm{Ac})$ as compared with the control, BSA-plus, culture (Figure $3 \mathrm{Aa}$ ) or with cells treated with SB202190 alone (Figure 3Ab). However, addition of SB202190 to cells treated with TGF- $\beta 2$ reduced the extent of induction of type I collagen (Figure $3 \mathrm{Ad})$. These results were confirmed in an ELISA assay, which showed enhanced production of type I collagen in cells treated with TGF- $\beta 2$, and a partial reduction when cells were simultaneously treated with the p38 MAPK inhibitor (Figure 3b). Similar results were obtained using either culture medium or cell lysate. Parallel results were observed for fibronectin production, using either immunocytochemistry (Figure 4a) or ELISA (Figure 4b). However, in this case, SB202190 reduced the level of fibronectin expression by TGF- $\beta 2$ to the level of inhibitor-treated control cells (Figure 4b).

\section{Cell Migration}

Frames a, e, i, $\mathrm{m}$ and $\mathrm{q}$ of Figure 5A show migration of cells in vehicle-treated cultures following a wounding defect in vitro. As expected, addition of TGF- $\beta 2$ significantly enhanced the migration of the cells (Figure 5A, b, f, j, n and r). Even at $12 \mathrm{~h}$ postwounding in TGF- $\beta 2$ culture, many cells were found to migrate out into the defected area from cell 

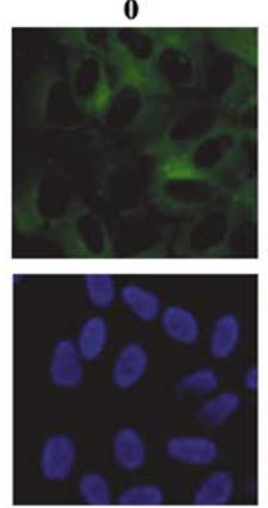

b
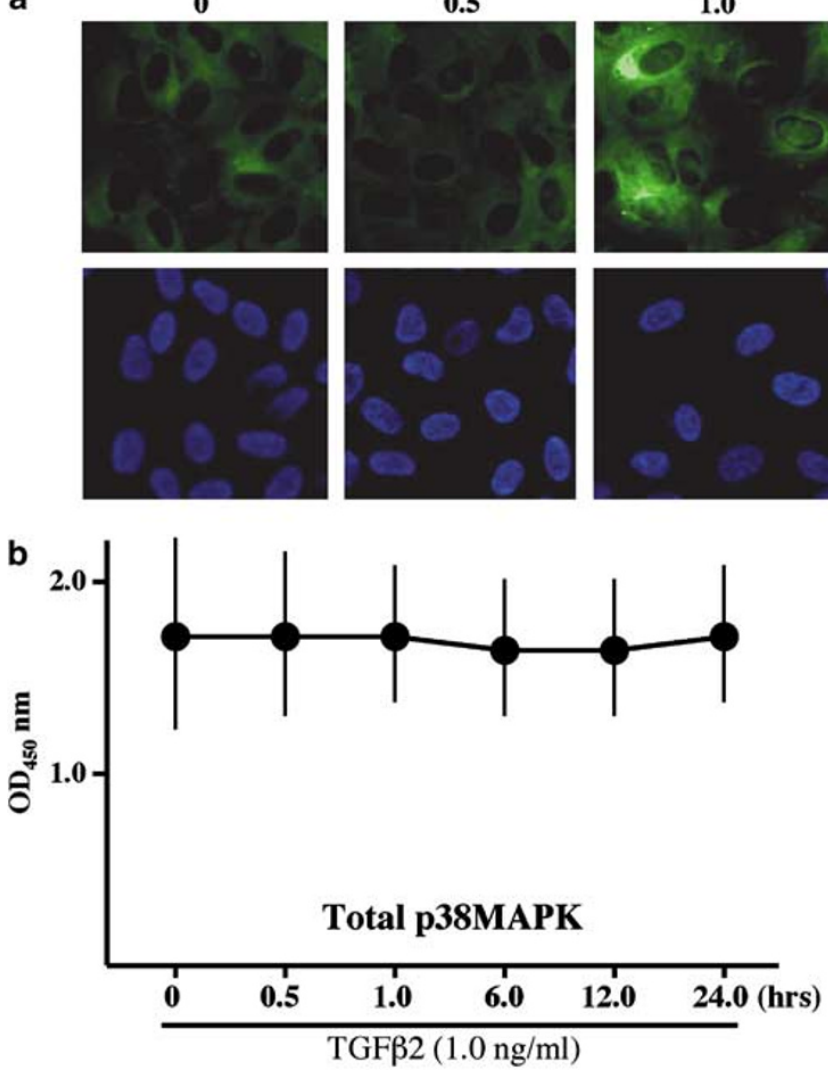

6.0
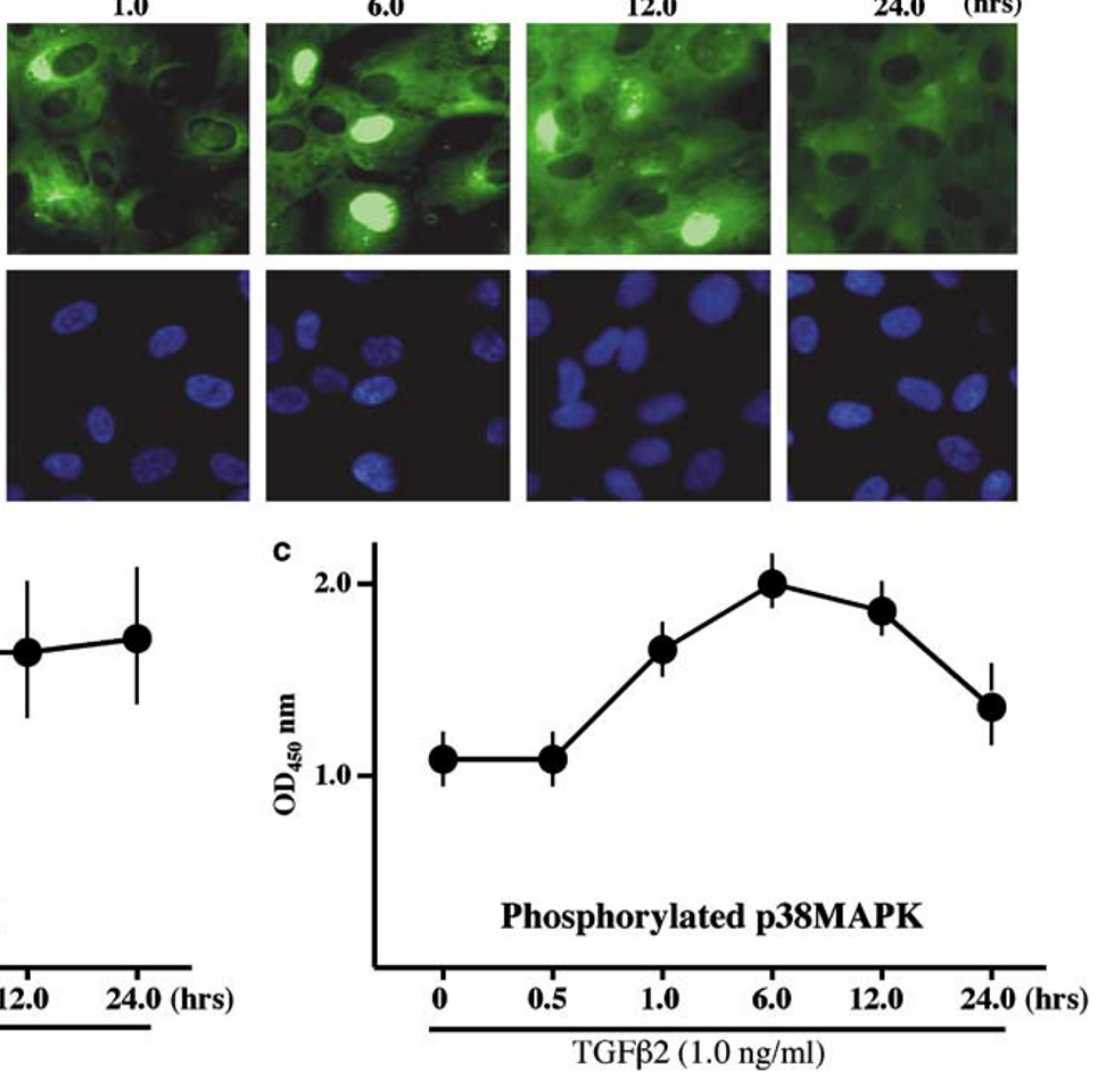

Figure 1 TGF- $\beta 2$ induces phosphorylation and nuclear translocation of p38 mitogen-activated protein kinase (MAPK) in ARPE-19 cells. Upper series of panel (a) shows transient nuclear translocation of phosphorylated p38MAPK in ARPE-19 cells from 0 to $24 \mathrm{~h}$ after addition of TGF- $\beta 2(1.0 \mathrm{ng} / \mathrm{ml})$. Faint basal level of phospho-p38MAPK is observed at time 0 and $0.5 \mathrm{~h}$. At $1 \mathrm{~h}$ cytoplasmic phosphop38MAPK is increased and marked nuclear translocation is detected at 6 and $12 \mathrm{~h}$, returning to baseline at $24 \mathrm{~h}$. Lower series indicates DAPI nuclear staining of the identical cells at each timepoint. Panels (b) and (c) indicate the level of total and phosphorylated p38MAPK in ARPE-19 cells during the time course following TGF- $\beta 2$ addition as determined by an ELISA assay. There is no change in the level of total p38MAPK, while phospho-p38MAPK transiently increases with a peak at $6 \mathrm{~h}$. Bar, standard deviation.

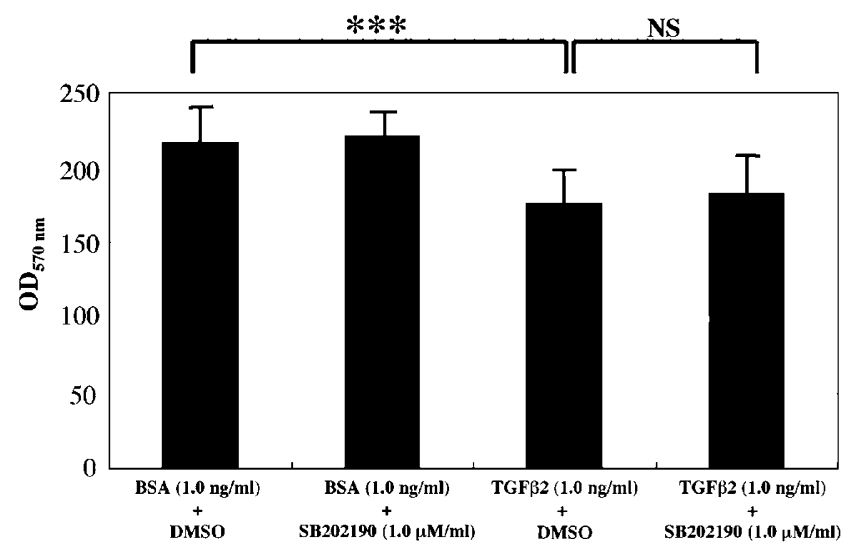

Figure 2 TGF- $\beta 2$, but not SB202190, suppresses proliferation of ARPE-19 cells. TGF- $\beta 2$ suppresses cell proliferation and no further inhibition is observed in culture with both TGF- $\beta 2$ and SB202190. \pm , standard deviation.

sheet. Addition of SB202190 had no effect on cell migration in the absence of exogenous TGF- $\beta 2$ (Figure 5A, c, g, k, o and s), but it suppressed cell migration stimulated by TGF- $\beta 2$ to the level of untreated cultures (Figure 5A, d, h, l, p and t). These data are quantitated in Figure 5B, which shows the $\%$ remaining defect in each culture condition. For this value, the width was measured at three independent points and the mean value was compared to the width of the original defect. The p38MAPK inhibitor abolished TGF- $\beta 2$-induced enhancement of wound closure by $24 \mathrm{~h}$.

\section{Effect of p38 Inhibitor on Smad Phosphorylation}

Since our results indicated that p38MAPK inhibitor, SB202190, reduced production of collagen type I and fibronectin, and since Smad signaling has been implicated in TGF- $\beta$-dependent induction of each of these proteins, we examined whether the p38MAPK inhibitor might directly affect C-terminal phosphorylation or transcriptional activity of Smads2/3. Western blotting of cell lysates showed that exposure to TGF- $\beta 2$ induces phosphorylation of Smads2/3 as early as $0.25 \mathrm{~h}$ and that the phosphorylation is sustained through $48 \mathrm{~h}$. Addition of SB202190 at $10 \mathrm{ng} / \mathrm{ml}$ had no effect on the 
C-terminal phosphorylation of Smads2/3, suggesting that this inhibitor does not interfere with receptormediated phosphorylation of Smads2/3 (Figure 6). However, transient transfection of ARPE-19 cells with a specific Smads3/4-dependent reporter gene, CAGA12-Luc, typically used to assess the transcriptional activating activity of Smad complexes, showed that both basal activity and TGF- $\beta 2$-induced activity of this reporter were significantly reduced in cells treated with SB202190 (Figure 7). These data suggest that p38MAPK contributes to activation of Smad proteins, likely through effects on phospho-
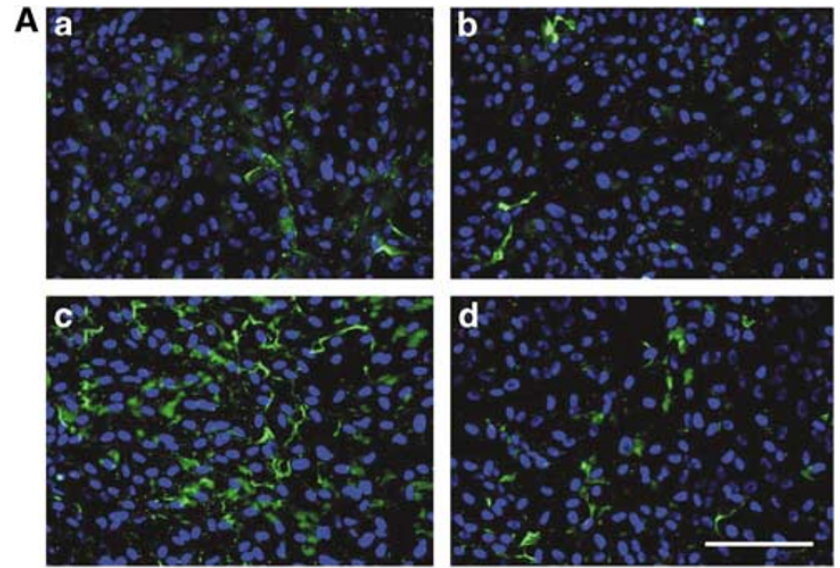

B

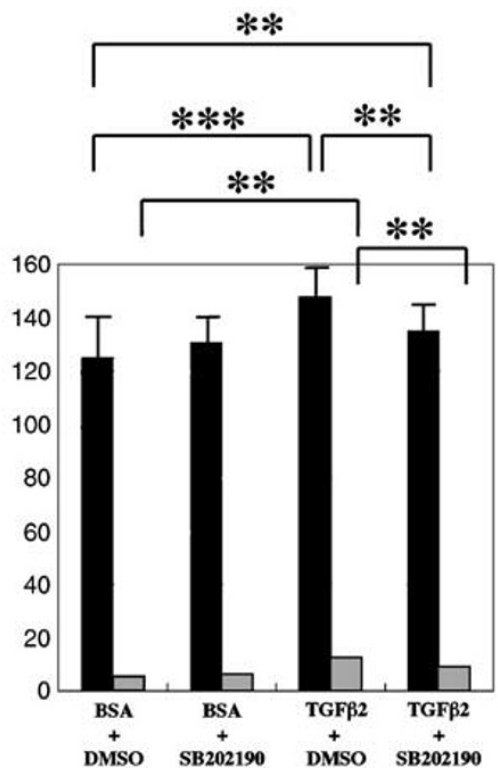

Figure 3 SB202190 reduces effects of TGF- $\beta 2$ on production of collagen type I in ARPE-19 cells. (A) Fluorescence immunocytochemistry with DAPI nuclear staining showed increased deposition of collagen type I in cells treated with TGF- $\beta 2$ (1.0 ng/ $\mathrm{ml}$ ) for $24 \mathrm{~h}$ (Ac) as compared with vehicle-treated cells (Aa) or cells treated with SB202190 (Ab). SB202190 alone had no effect on basal levels of collagen I expression (Ab), whereas addition of SB202190 to the TGF-b2-treated cells reduced deposition of type I collagen substantially (Ad). bar, $100 \mu \mathrm{m}$; Quantitation of type I collagen under the various treatment conditions by an ELISA assay (B). Solid or dotted bar, type I collagen in culture medium or cell lysate, respectively. \pm , standard deviation. rylation sites other than the C-terminal site phosphorylated by the Type I receptor.

\section{Histology and Immunohistochemical Observation of a Mouse PVR Model Treated with Adenoviral Gene Transfer of DN p38MAPK}

The efficacy of the adenoviral gene transfer to retinal pigment epithelial cells in vivo was examined in unfixed cryosections of eyes treated with GFP-Ad. The fluorescence generated by GFP was readily detected in pigment epithelial cells and cells presumed to be derived from the pigment epithelium in
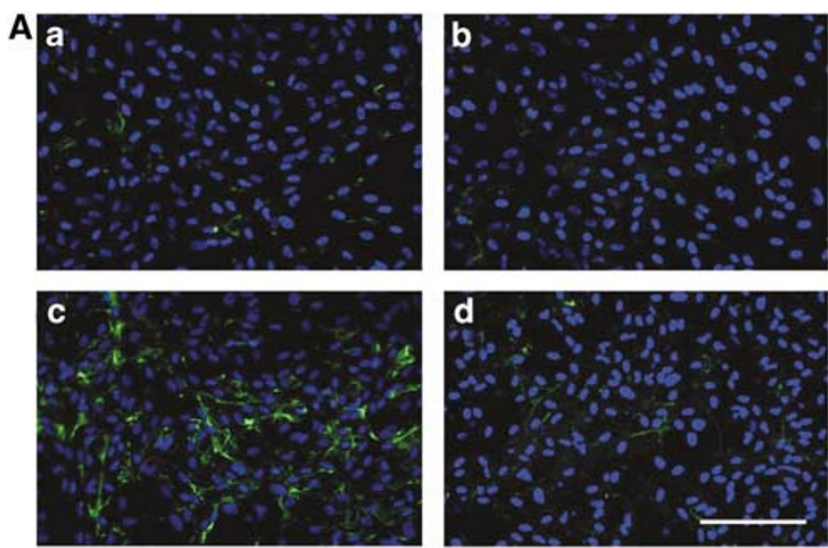

B

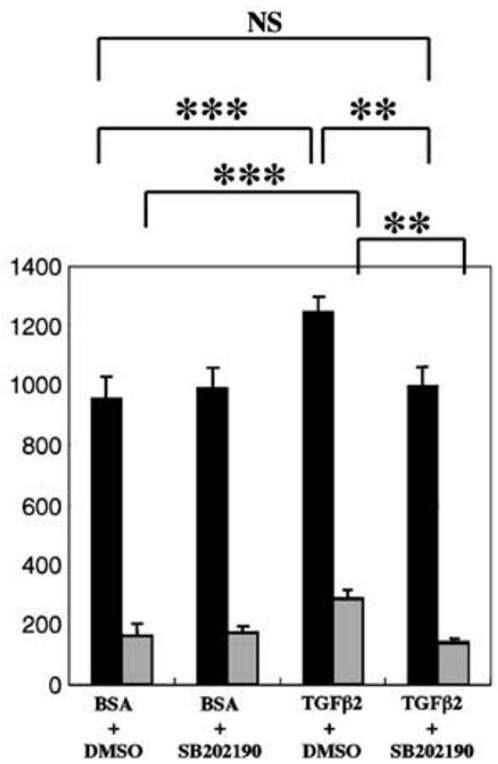

Figure 4 SB202190 blocks the ability of TGF- $\beta 2$ to induce production of fibronectin in ARPE-19 cells. Fluorescence immunocytochemistry with DAPI nuclear staining showed increased deposition of fibronectin in cells treated with TGF- $\beta 2$ $(1.0 \mathrm{ng} / \mathrm{ml})$ for $24 \mathrm{~h}(\mathrm{Ac})$ as compared with vehicle-treated cells (Aa) or cells treated with SB202190 (Ab). SB202190 alone had no effect on basal levels of fibronectin expression (Ab), whereas addition of SB202190 to the TGF- $\beta 2$-treated cells reduced deposition of fibronectin substantially (Ad). Bar, $100 \mu \mathrm{m}$. Quantitation of fibronectin under the various treatment conditions by an ELISA assay (B). Solid or striped bar, type I collagen in culture medium or cell lysate, respectively. \pm , standard deviation. 
844

A

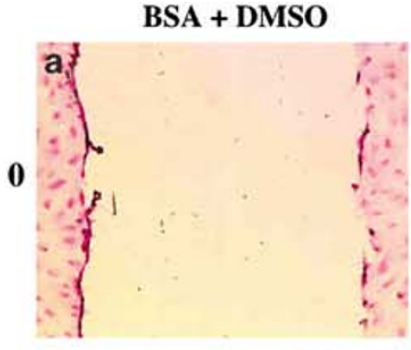

\section{e?:}

12
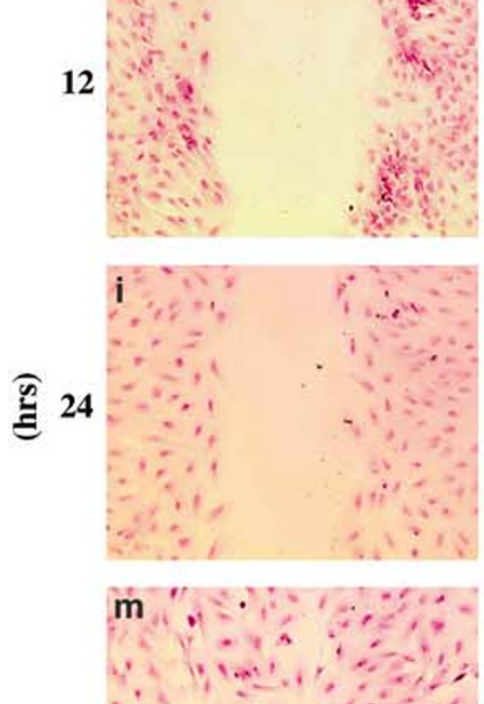

48

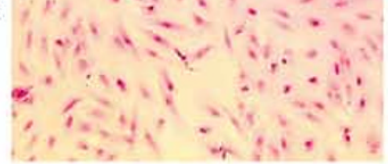

q

72
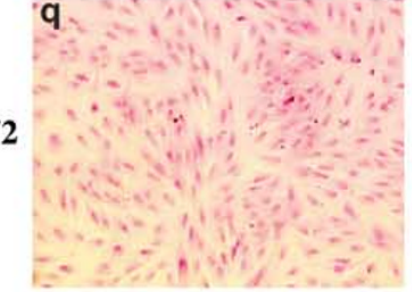

TGF $\beta 2$ + DMSO
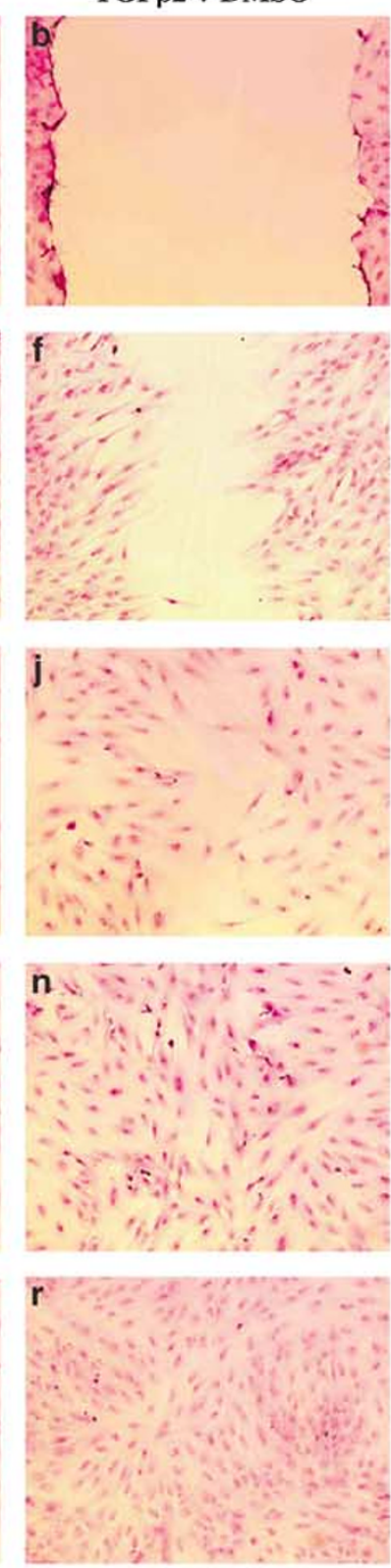
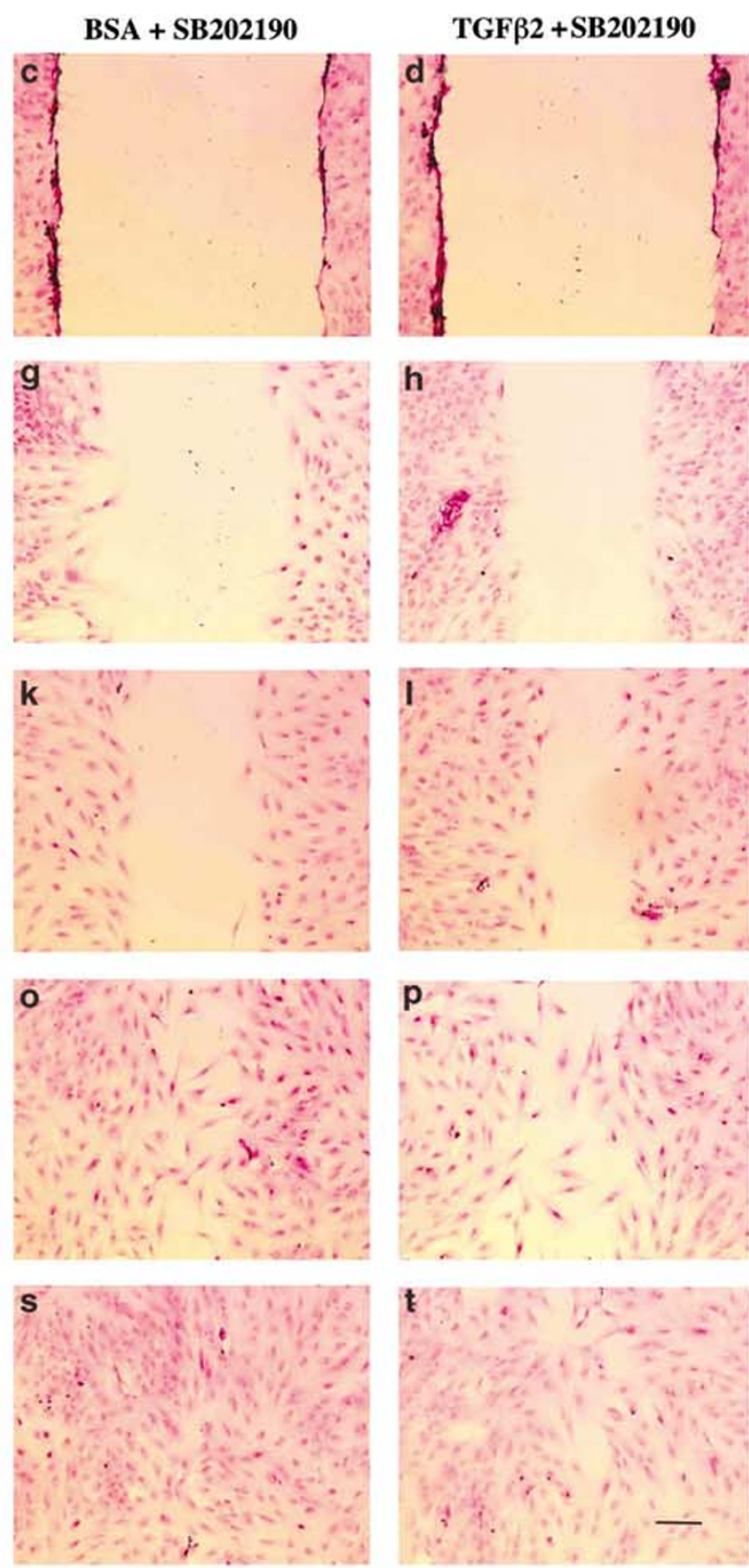

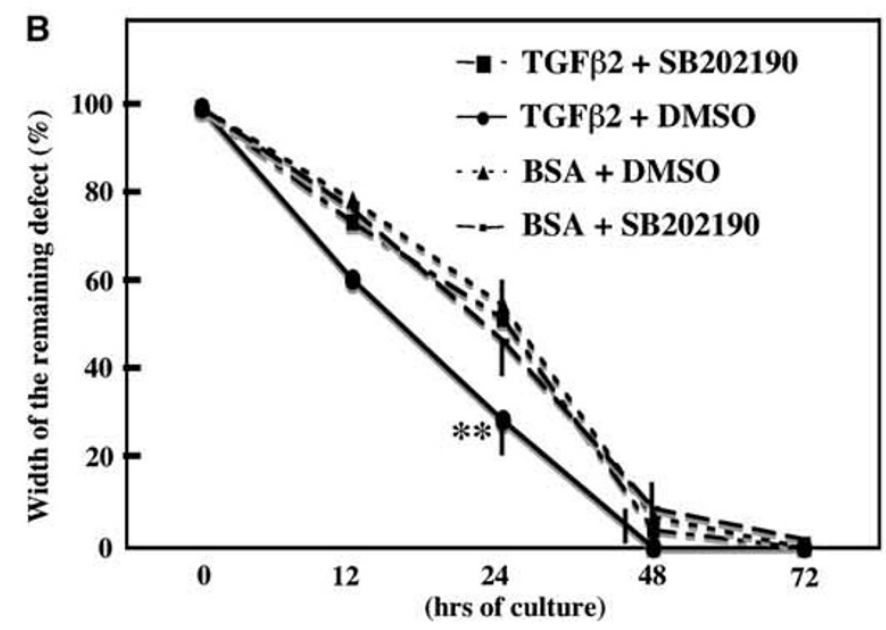




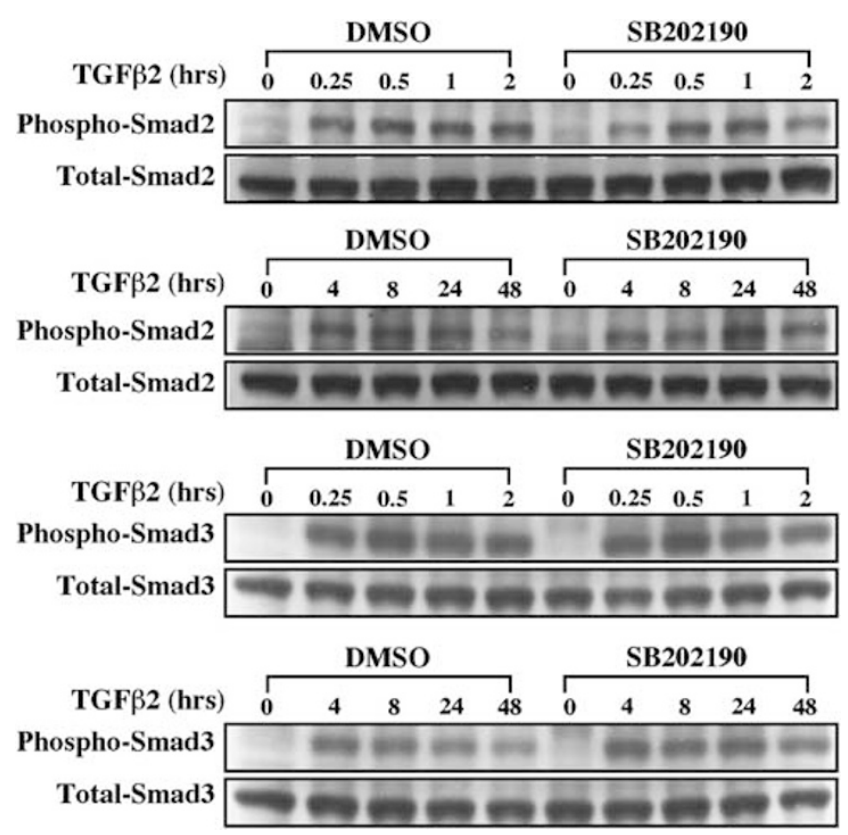

Figure 6 SB202190 has no effect on phosphorylation of the Cterminus of Smads2/3 induced by TGF-b2. Western blotting for phospho-Smad2 or phospho-Smad3 (see Materials and methods) in ARPE-19 cells show that TGF-b2 $(1.0 \mathrm{ng} / \mathrm{ml})$ induces phosphorylation of both Smad2 and Smad3 as early as $0.25 \mathrm{~h}$ and its phosphorylation persists up to $48 \mathrm{~h}$ in control, DMSO culture. SB202190 $(10 \mu \mathrm{M})$ has no effect.

the fibrotic tissue formed on the injured pigment epithelial layer at days 1-10, but was faintly seen at day 20 (data not shown), but not with LacZ-Ad. Furthermore, expression of the introduced DN p38MAPK gene was examined by immunodetection of the HA-Tag. Expression of the HA-Tag was also readily detected at days 1-10 (Figure 8a, f, day 5), but faintly observed at day 20 , indicating the successful introduction of DN p38MAPK by using adenoviral gene transfer.

We then examined the expression of phosphop38MAPK in tissues to determine if DN p38MAPK suppressed p38MAPK activity in pigment epithelial cells. Figure 8b-e show that retinal pigment epithelial cells on the Bruch's membrane and cells in the fibrotic tissues formed on the Bruch's membrane in the control LacZ-Ad group specimens were labeled with anti-phospho-p38MAPK antibody, whereas those in DN p38MAPK-Ad group specimens were not, or only faintly, stained (Figure $8 \mathrm{~g}-\mathrm{j}$ ). At day 2, the injured pigment epithelium does not show

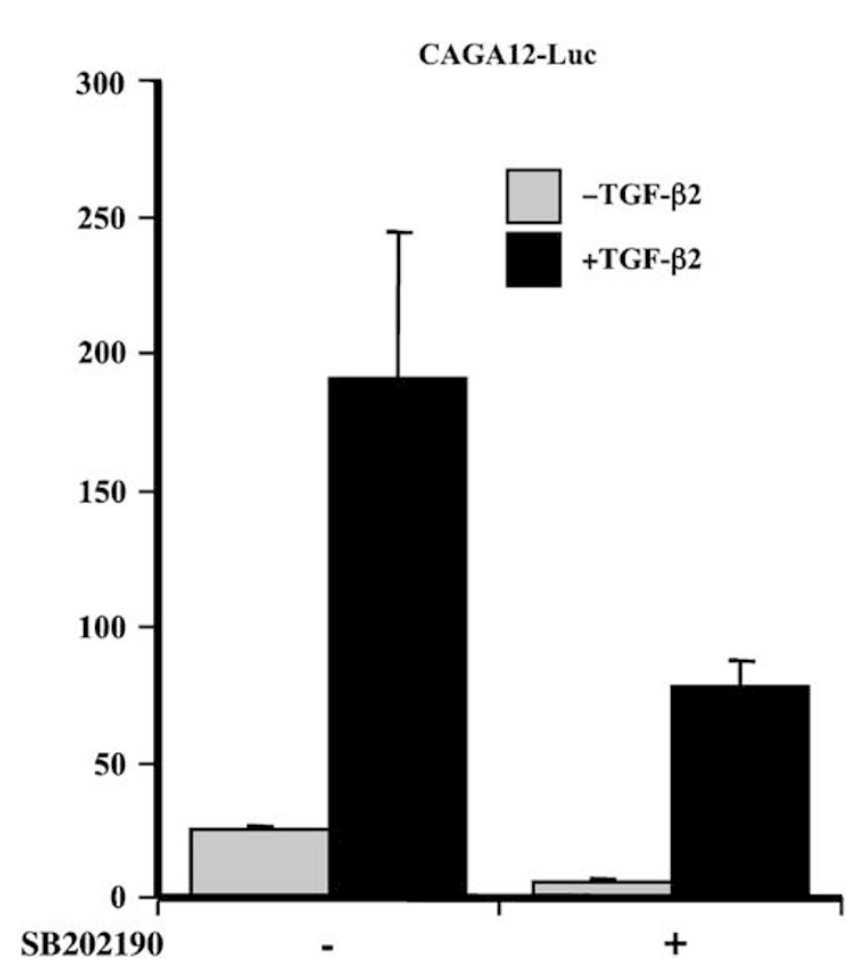

Figure 7 SB202190 significantly reduces both the basal and TGF$\beta 2$-induced transcriptional activity of Smads3/4 in a reporter gene assay. Transient transfection of ARPE-19 cells with the Smads3/4 reporter CAGA12-Luc as described in Materials and methods demonstrates that pretreatment of the cells with the p38 inhibitor SB202190 reduces both the basal and the TGF- $\beta 2$-induced transcriptional activity as measured in a luciferase assay. Results are the average \pm standard deviation of triplicates. Transfection efficiency is controlled internally by measurement of renilla luciferase.

multilayerization regardless the genes introduced (Figure 9a, a', d, d'), but at day 5 pigment epithelial cells exhibited a cell multilayer in control Ad group (Figure 9b, $b^{\prime}$ ), whereas those in DN p38MAPK-Ad group (Figure 9e, e $\mathrm{e}^{\prime}$ ) did not. At day 10, dense fibrous tissue containing pigmented cells was formed in the vitreous cavity in control Ad-treated eyes (Figure 9c, $c^{\prime}$ ), but only minor cell multilayerization was observed on the Bruch's membrane in DN p38MAPK-Ad-treated eyes (Figure 9f, $\mathrm{f}^{\prime}$ ).

$\alpha \mathrm{SMA}$ is the hallmark of development of fibrotic tissue and is known to be expressed by retinal pigment epithelial cells that have been transformed to fibroblastic cells. Immunohistochemistry of $\alpha$ SMA showed that pigment epithelial cells are

Figure 5 SB202190 decreases TGF- $\beta 2$-stimulated migration of ARPE-19 cells following wounding in vitro. (A) Frames a-d, e-h, I-l, m-p and $\mathrm{q}-\mathrm{t}$ indicate the defect produced in a monolayer of ARPE-19 cells at $0,12,24,48$, and $72 \mathrm{~h}$, respectively. Panels show migration of vehicle-treated cells (a, e, i, m, q), cells treated with TGF- $\beta 2(1.0 \mathrm{ng} / \mathrm{ml})(\mathrm{b}, \mathrm{f}, \mathrm{j}, \mathrm{n}, \mathrm{r})$, cells treated with SB202190 (10 $\mu \mathrm{M} / \mathrm{ml})$ alone (c, g, k, $\mathrm{o}, \mathrm{s})$, or the combination of TGF- $\beta 2$ and SB202190 (d, h, l, p, t). SB202190 has no effect on the basal rate of closure of the defect but decreases the rate of closure in cultures treated with TGF- $\beta 2$. Hematoxylin and eosin staining; bar, $100 \mu \mathrm{m}$. (B) Percent remaining defect in monolayer cell sheet. TGF- $\beta 2$ significantly enhances defect closure and addition of SB202190 reduces the rate of closure in the presence of TGF- $\beta 2$. The data show the \% remaining defect in each culture condition. For this value, the width was measured at three independent points and the mean value was compared to the width of the original defect. ${ }^{* *}$ statistically significant $P<0.05$; Bar, standard deviation. 

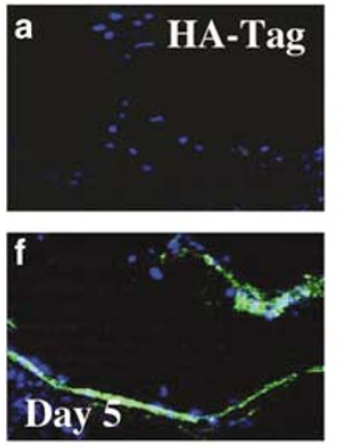

HA-Tag
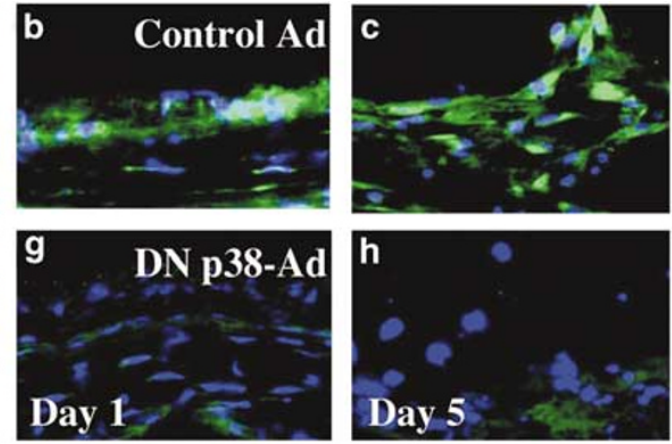

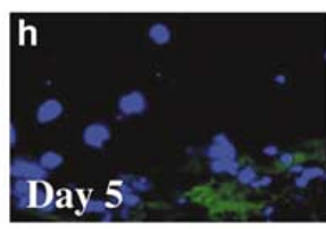

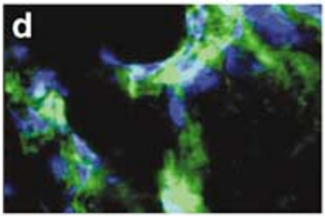

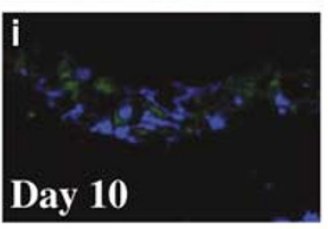

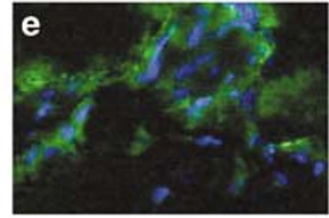

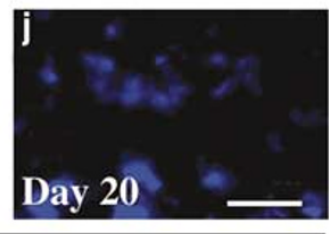

Phospho-p38MAPK

Figure 8 Expression of HA-Tag and phospho-p38MAPK in experimental PVR eyes treated with DN p38MAPK-adenoviral vector or control LacZ-Ad. Expression of the introduced gene was confirmed by immunohistochemical detection of the HA-Tag at day 5 (F) in DN p38MAPK-Ad group specimens. In control LacZ-Ad group specimens positive labeling was not observed (a). Phospho-p38MAPK was readily detected in retinal pigment epithelial cells in control LacZ-Ad-treated tissues at days 1 (b), 5 (c), 10 (d), and 20, but was not in those treated with DN p38MAPK-Ad (g-j). Bar, $20 \mu \mathrm{m}$ (a, f), $10 \mu \mathrm{m}(\mathbf{b}-\mathbf{e}, \mathbf{g}-\mathbf{j})$.

labeled with anti- $\alpha$ SMA antibody (Figure 10a, white arrows) in control LacZ-Ad specimens, but not in DN p38MAPK-Ad specimens (Figure 10d, yellow arrows) at day 2. At days 5 (Figure 10b, e) and 10 (Figure 10c, f), the cells exhibit immunoreactivity for $\alpha \mathrm{SMA}$ in both groups, but the $\alpha \mathrm{SMA}$ label was more prominent in control eyes (Figure 10b, c) as compared with eyes of the DN p38MAPK-Ad (Figure 10e, f) group. Expression of type VI collagen shows a pattern similar to that of $\alpha$ SMA. Pigment epithelial cells are not labeled with anti-collagen VI antibody in control (Figure 10g, yellow arrows) and DN p38MAPK-Ad specimens (Figure 10j, yellow arrows) at day 2. At day 5, the control tissue contains multilayers of cells labeled with anticollagen VI antibody (Figure 10h, white arrow), but not in the DN p38MAPK-Ad group (Figure 10k, yellow arrow). At day 10 (Figure 10i, l), the newly formed fibrous tissues exhibit more immunoreactivity for collagen VI in the control group (Figure 10i) as compared with the DN p38MAPK-Ad (Figure 10l) group.

\section{Discussion}

In the present study, we have utilized a human retinal pigment epithelial cell line, ARPE-19 cell, ${ }^{32}$ to demonstrate that inhibition of p38MAPK by the specific inhibitor, SB202190, interferes with stimulatory effects of exogenous TGF- $\beta 2$ on migration of cells and on production of ECM components, such as collagen type I and fibronectin, while having no effects on the basal levels of these effects. These findings suggest that stimulation of cell migration and ECM production by TGF- $\beta 2$ likely results from cooperative effects of multiple signaling inputs including p38MAPK and further that these signals are probably different from signaling pathways utilized in maintaining the basal activity of these end points, which appears to be independent of
p38MAPK. While we have shown that these effects of the p38MAPK inhibitor are not due to direct interference with activation of the TGF- $\beta$ signal transducers, Smad2 and Smad3, by receptormediated C-terminal phosphorylation, our data suggest that p38MAPK positively affects the transcriptional activity of Smads2/3, possibly by phosphorylation of Smads2/3 on other residues such as might be found in the C-terminal or middle linker domains. Indeed, it has recently been demonstrated that p38MAPK can lead to activating phosphorylation of Smad3 in the middle linker region, which enhanced Smads3/4 complex formation and nuclear translocation, ${ }^{36}$ consistent with our finding of diminished Smads3/4 reporter gene activity in the presence of the p38MAPK inhibitor. It has been recently reported that such phosphorylation by MAP kinases in the Smad3 linker region is required for the full activation of Smad signaling. ${ }^{18,19}$ Cooperative effects of signaling through p38MAPK and the Smad cascade by exogenous TGF- $\beta$ are well documented. For example, induction of MMP-13 or aggrecan gene expression by TGF- $\beta$ requires activation of both Smad and p38MAPK cascades as does apoptosis in hepatocytes. ${ }^{38,39}$ Moreover, p38 may affect these end points not only by direct activation of the Smad proteins via phosphorylation of residues in the middle linker region, ${ }^{40}$ but also by activation of cooperating transcription factors. For example, TGF- $\beta$-activated kinase (TAK1) has been shown to be an upstream activator of MKK6 and activation of this pathway results in phosphorylation of activating transcription factor 2 (ATF2) and enhancement of complex formation between Smad4 and ATF2. ${ }^{41,42}$ However, another report shows that Smad and p38MAPK independently regulate collagen I $\alpha 1$ mRNA in hepatic stellate cells ${ }^{41}$ and thus further study will be needed to uncover gene expression regulation by TGF- $\beta$. Regardless, attenuation of TGF- $\beta 2$-dependent effects on migration and production of ECM by ARPE-19 cells by 

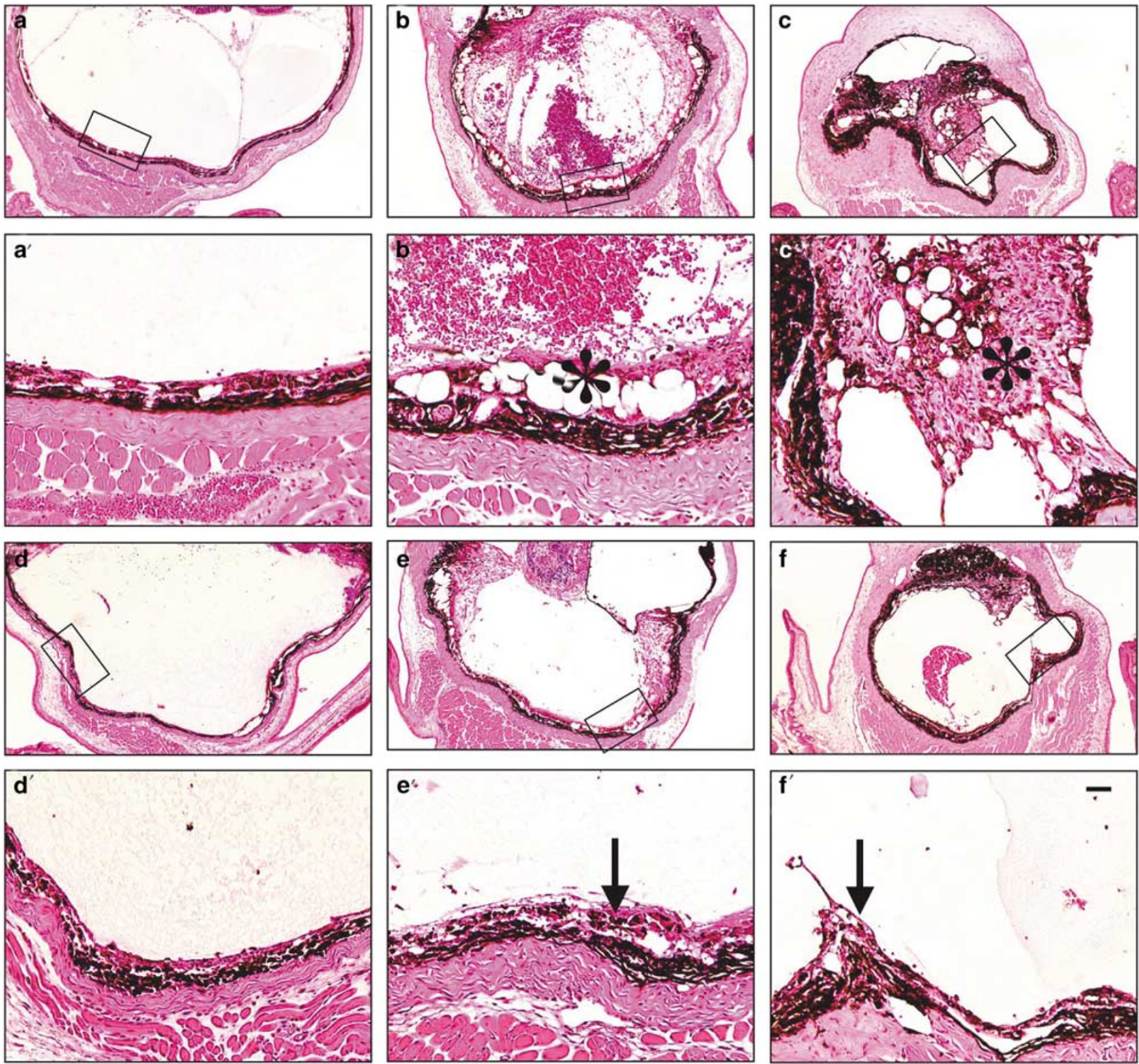

Figure 9 Histology of mouse PVR eyes treated with either control LacZ- or DN p38MAPK-adenoviral vector at days 2, 5, and 10. At day 2 the injured pigment epithelium does not show multilayerization in either the LacZ-Ad- $\left(\mathbf{a}, \mathbf{a}^{\prime}\right)$ or DN p38MAPK-Ad-treated eyes (d, $\left.\mathbf{d}^{\prime}\right)$. At day 5, pigment epithelial cells exhibited a cell multilayer in the control, LacZ-Ad group (b, $\mathbf{b}^{\prime}$, asterisk), whereas those in DN p38MAPKAd group (e, $\mathbf{e}^{\prime}$, arrow) did not. At day 10 dense fibrous tissue containing pigmented cells was formed in the vitreous cavity in LacZ-Adtreated eyes (c, $\mathbf{c}^{\prime}$, asterisk), but only minor cell multilayerization was observed on the Bruch's membrane in DN p38MAPK-Ad-treated eyes (f, $\mathbf{f}^{\prime}$, arrow). Panels $\mathbf{a}^{\prime}-\mathbf{f}^{\prime}$ show higher magnification pictures of boxed areas in frames $(\mathbf{a}-\mathbf{f})$, respectively. Bar, $150 \mu \mathrm{m}(\mathbf{a}-\mathbf{f}), 20 \mu \mathrm{m}\left(\mathbf{a}^{\prime}-\mathbf{f}^{\prime}\right)$.

addition of a p38MAPK inhibitor suggests that such an inhibitor might be efficacious in the prevention/ treatment of PVR.

In the present study, we found that peak of phosphorylation of p38 MAPK occurred at $6 \mathrm{~h}$ post-TGF- $\beta 2$ addition. Other reports frequently instead demonstrated that such p38 activation peaks occurred at earlier time points, that is, $15 \mathrm{~min}$ to $2 \mathrm{~h}$, depending on cell types. ${ }^{43,44}$ Although we are unable to explain this discrepancy, it is possible that this difference could be explained by the finding that protein phosphatase-2A, which is potentially activated by TGF- $\beta$, might dephosphorylate activated p38 at early times. ${ }^{45}$ However, we failed to examine whether the mechanism of p38 phosphorylation at the peak of $6 \mathrm{~h}$ was induced by the direct effect of binding TGF- $\beta 2$ to the receptor or by secondary effects of other growth factors induced by TGF- $\beta 2$. Alternatively, our use of the ELISA system might not detect an early subtle upregulation of phospho-p38.

TGF- $\beta 2$ enhanced the production of collagen type I even in the presence of the p38 inhibitor, 


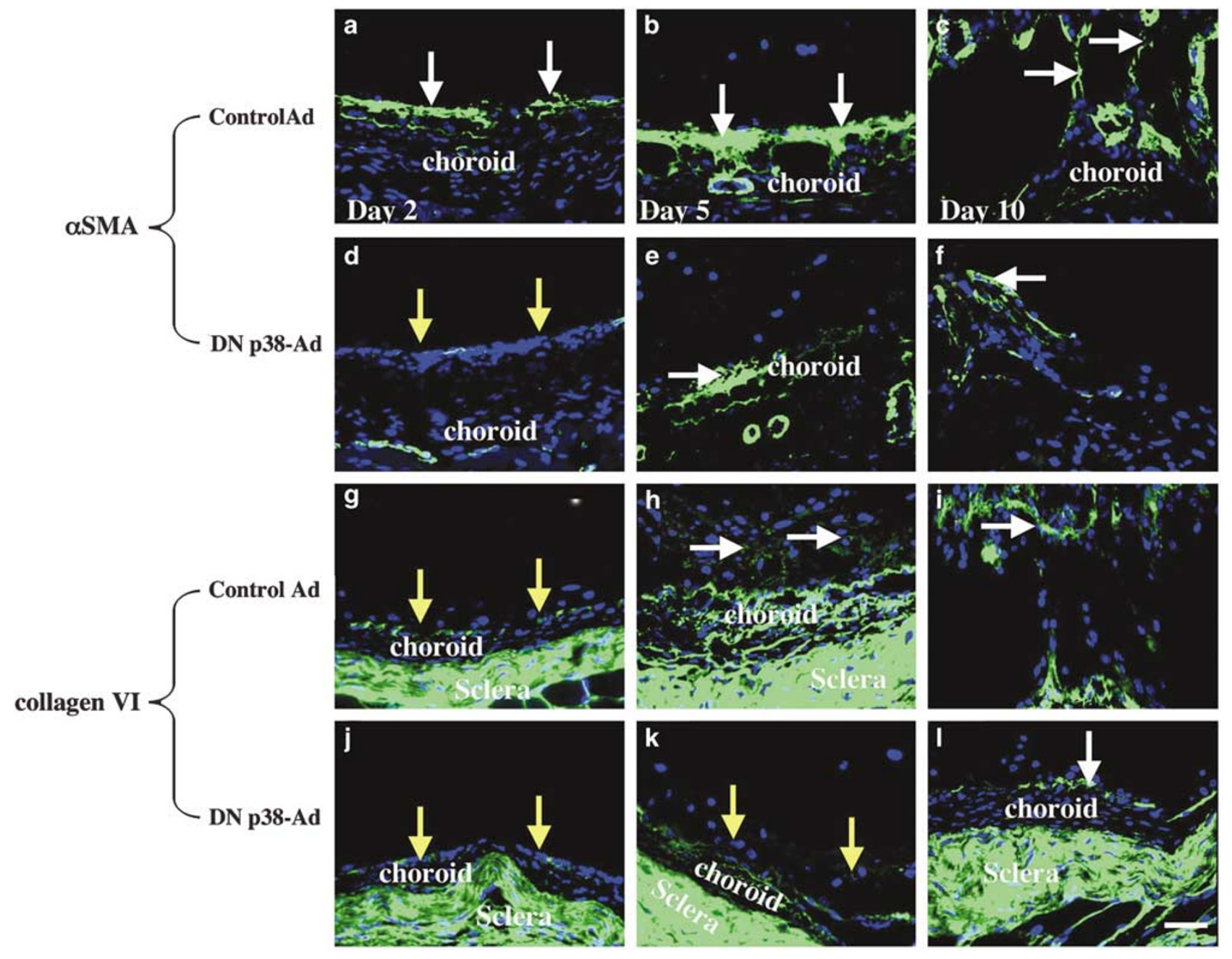

Figure 10 Expression of $\alpha$ SMA and collagen type VI in experimental PVR mouse eyes treated with either control LacZ-Ad or DN p38MAPK-Ad. At day 2 pigment epithelial cells were labeled with anti- $\alpha$ SMA antibody (a, white arrows) in LacZ-Ad control specimens, but not in DN p38MAPK-Ad specimens (d, yellow arrows). At days 5 (b, e) and 10 (c, f) the cells in the control group exhibit more prominent immunoreactivity for $\alpha$ SMA (white arrows, b, c) than in the DN p38MAPK-Ad (white arrows, e, f) group. At day 2 pigment epithelial cells were not labeled with anti-collagen VI antibody in control (g, yellow arrows) and DN p38MAPK-Ad specimens (j, yellow arrows). At day 5 , the tissue containing cell multilayerization was labeled with anti-collagen VI antibody in control specimens (h, white arrow), but not in DN p38MAPK-Ad specimens (k, yellow arrow). At day 10, the immunoreactivity for collagen VI was more prominent in control (i) than in DN p38MAPK-Ad (l) samples. Bar, $20 \mu \mathrm{m}$.

indicating that TGF- $\beta 2$-dependent enhancement of type I collagen production is dependent on both non-p38MAPK and p38MAPK signaling. In contrast, effects of TGF- $\beta 2$ on fibronectin were almost totally abrogated by the p38 inhibitor, suggesting that TGF$\beta 2$-dependent induction of fibronectin is more dependent on p38MAPK as compared to collagen I. This is consistent with reports showing that induction of type I collagen by TGF- $\beta$ requires Smad $3^{46}$ whereas induction of fibronectin is independent of Smad signaling and dependent instead on the JNK pathway, ${ }^{47}$ or possibly in ARPE-19 cells on p38MAPK. Alternatively, induction of fibronectin expression by TGF- $\beta 2$ in ARPE-19 cells may result from activation of p38MAPK downstream of Smad signaling as shown for TGF- $\beta$-dependent induction of thrombospondin-1 expression and apoptosis. ${ }^{48}$ Both of these end points are mediated by p38MAPK that is first activated by TGF- $\beta /$ Smad signaling through upregulation of GADD45b. ${ }^{38,49}$ Clearly, further study is needed to clarify the hierarchy of signaling pathways involved in induction of fibronectin expression by TGF- $\beta$.

TGF- $\beta 2$-induced migration of ARPE-19 cells was also dependent on p38MAPK, as SB202190 reversed the enhanced cell migration in response to exogenous TGF- $\beta 2$. This result is consistent with previous studies demonstrating an involvement of p38MAPK in promotion of cell migration of epidermal keratinocytes, mammary epithelial cell line or others. ${ }^{19-25}$ In other studies, we have also shown that loss of Smad3, the key mediator of TGF- $\beta$ signaling from cell surface receptors, results in loss of chemotactic responses to TGF- $\beta$ in keratinocytes, 
monocytes and fibroblasts in vitro. ${ }^{49,50}$ Whether chemotactic cell movement also involves the p38MAPK pathway is not known, nor is it known whether TGF- $\beta 2$-dependent migration of ARPE-19 cells postinjury in vitro depends exclusively on signals through p38MAPK or on crosstalk between p38MAPK and Smad signaling. In our study, cell migration enhancement was morphologically observed at $12 \mathrm{~h}$ postwounding, although statistical significance was detected only at $24 \mathrm{~h}$. In another study, TGF- $\beta 1$ enhanced migration of another retinal pigment epithelial cell line, human RPE cell line D407, after $72 \mathrm{~h}^{51}$ This difference might be due to a difference between the cells lines used in the two studies.

p38MAPK has also been shown to be required for TGF- $\beta$-dependent stimulation of matrix production in dermal fibroblasts, and thus inhibition of p38MAPK could potentially be effective in preventing dermal scarring. ${ }^{24,26,30}$ It has also been shown that p38MAPK-dependent activation of Smad3 promoted deposition of extracellular matrix by myofibroblasts both in vitro and in vivo. ${ }^{24,26,30,31}$ These reports together with our findings lead us to hypothesize that inhibition of p38MAPK may be beneficial in preventing/treating PVR. Although PVR is caused by the activation of many cell types, that is, retinal glial components, vascular cells, and so on, activation and fibroblastic transformation of $\mathrm{RPE}$ cells is a critical feature in the development of this disease. Our results clearly demonstrate that DN p38MAPK suppresses fibrotic reaction by retinal pigment epithelial cells in an experimental mouse PVR model. Further study is needed to establish the clinical application of this treatment strategy.

\section{Acknowledgements}

We thank Dr Ed Leof for his generous gift of antiphospho-Smad3 antibody. This study was supported by a Grant from the Ministry of Education, Science, Sports and Culture of Japan (No. 15591871) and Uehara Memorial Foundation (to SS), and a Research Grant on Priority Areas from Wakayama Medical University (to SSYM, and AO).

\section{References}

1 Pastor JC, de la Rua ER, Martin F. Proliferative vitreoretinopathy: risk factors and pathobiology. Prog Retin Eye Res 2002;21:127-144.

2 Bochaton-Piallat ML, Kapetanios AD, Donati G, et al. TGF- $\beta 1$, TGF- $\beta$ receptor II and ED-A fibronectin expression in myofibroblast of vitreoretinopathy. Invest Ophthalmol Vis Sci 2000;41:2336-2342.

3 Sheridan CM, Occleston NL, Hiscott P, et al. Matrix metalloproteinases: a role in the contraction of vitreo-retinal scar tissue. Am J Pathol 2001;159: 1555-1566.
4 Roberts AB, Sporn MB. The transforming growth factors- $\beta$. In: Sporn MB, Roberts AB (eds). Handbook of Experimental Pharmacology. Peptide Growth Factors and their Receptors. Springer-Verlag: New York, 1990, pp 419-472.

5 Carrington L, McLeod D, Boulton M. IL-10 and antibodies to TGF- $\beta 2$ and PDGF inhibit RPE-mediated retinal contraction. Invest Ophthalmol Vis Sci 2000;41: 1210-1216.

6 Cassidy L, Barry P, Shaw C, et al. Platelet derived growth factor and fibroblast growth factor basic levels in the vitreous of patients with vitreoretinal disorders. Br J Ophthalmol 1998;82:181-185.

7 Choudhury P, Chen W, Hunt RC. Production of platelet-derived growth factor by interleukin-1 beta and transforming growth factor-beta-stimulated retinal pigment epithelial cells leads to contraction of collagen gels. Invest Ophthalmol Vis Sci 1997;38: 824-833.

8 Hinton DR, He S, Jin ML, et al. Novel growth factors involved in the pathogenesis of proliferative vitreoretinopathy. Eye 2002;16:422-428.

9 Jaffe GJ, Harrison CE, Lui GM, et al. Activin expression by cultured human retinal pigment epithelial cells. Invest Ophthalmol Vis Sci 1994;35:2924-2931.

10 Taylor LM, Khachigian LM. Induction of plateletderived growth factor B-chain expression by transforming growth factor-beta involves transactivation by Smads. J Biol Chem 2000;275:16709-16716.

11 Yamamoto T, Takeuchi S, Suzuki K, et al. Expression and possible roles of activin A in proliferative vitreoretinal diseases. Jpn J Ophthalmol 2000;44:221-226.

12 Connor Jr TB, Roberts AB, Sporn MB, et al. Correlation of fibrosis and transforming growth factor-beta type 2 levels in the eye. J Clin Invest 1989;83:1661-1666.

13 Casaroli-Marano RP, Pagan R, Vilaro S. Epithelialmesenchymal transition in proliferative vitreoretinopathy: intermediate filament protein expression in retinal pigment epithelial cells. Invest Ophthalmol Vis Sci 1999;40:2062-2072.

14 Grisanti S, Guidry C. Transdifferentiation of retinal pigment epithelial cells from epithelial to mesenchymal phenotype. Invest Ophthalmol Vis Sci 1995;36: 391-405.

15 Lee SC, Kwon OW, Seong GJ, et al. Epitheliomesenchymal transdifferentiation of cultured RPE cells. Ophthalmic Res 2001;33:80-86.

16 Shi Y, Massague J. Mechanisms of TGF- $\beta$ signaling from cell membrane to the nucleus. Cell 2003;113: $685-700$.

17 ten Dijke P, Goumans MJ, Itoh F, et al. Regulation of cell proliferation by Smad proteins. J Cell Physiol 2002;191:1-16.

18 Mulder KM. Role of Ras and Mapks in TGF $\beta$ signaling. Cytokine Growth Factor Rev 2000;11:23-35.

19 Kamaraju AK, Roberts AB. Role of Rho/ROCK and p38 MAP kinase pathways in transforming growth factorbeta-mediated Smad-dependent growth inhibition of human breast carcinoma cells in vivo. J Biol Chem 2005;280:1024-1036.

20 Geller SF, Lewis GP, Fisher SK. FGFR1 signaling and AP-1 expression after retinal detachment: reactive Muller and RPE cells. Invest Ophthalmol Vis Sci 2001;42:1363-1369.

$21 \mathrm{Yu}$ L, Hebert MC, Zhang Y. TGF- $\beta$ receptor-activated p38 MAP kinase mediates Smad-independent TGF- $\beta$ responses. EMBO J 2002;21:3749-3759. 
22 Bakin AV, Rinehart C, Tomlinson AK, et al. P38 mitogen-activated protein kinases is required for TGF $\beta$-mediated fibroblastic transdifferentiation and cell migration. J Cell Sci 2002;115:3193-3206.

23 Klekotka PA, Santoro SA, Zutter MM. Alpha 2 integrin subunit cytoplasmic domain-dependent cellular migration requires p38 MAPK. J Biol Chem 2001;276: 9503-9511.

24 Li W, Nadelman C, Henry G, et al. The p38-MAPK/ SAPK pathway is required for human keratinocyte migration on dermal collagen. J Invest Dermatol 2001; 117:1601-1611.

25 Vadlamudi R, Adam L, Talukder A, et al. Serine phosphorylation of paxillin by heregulin- $\beta 1$ : role of p38 mitogen activated protein kinase. Oncogene 1999;18:7253-7264.

26 Bhowmick NA, Zent R, Ghiassi M, et al. Integrin $\beta 1$ signaling is necessary for transforming growth factor- $\beta$ activation of p38MAPK and epithelial plasticity. J Biol Chem 2001;276:46707-46713.

27 Dumon N, Bakin AV, Arteaga CL. Autocrine transforming growth factor- $\beta$ signaling mediates Smad-independent motility in human cancer cells. J Biol Chem 2003; 278:3275-3285.

28 Saika S, Okada Y, Miyamoto T, et al. Role of p38MAP kinase in regulation of cell migration and proliferation in healing corneal epithelium. Invest Ophthalmol Vis Sci 2004;45:100-109.

29 Sharma GD, He J, Bazan HE. p38 and ERK1/2 coordinate cellular migration and proliferation in epithelial wound healing: evidence of cross-talk activation between MAP kinase cascades. J Biol Chem. 2003;278:21989-21997.

30 Sato M, Shegogue D, Gore EA, et al. Role of p38 MAPK in transforming growth factor $\beta$ stimulation of collagen production by scleroderma and healthy dermal fibroblasts. J Invest Dermatol 2002;118:704-711.

31 Msamune A, Satoh M, Kikuta K, et al. Inhibition of p38 mitigen-activated protein kinase blocks activation of rat pancreatic stellate cells. J Pharmacol Exp Therap 2003;304:8-14.

32 Dunn KC, Aotaki-Keen AE, Putkey FR, et al. ARPE-19, a human retinal pigment epithelial cell line with differentiated properties. Exp Eye Res 1996;62: 155-169.

33 Saika S, Ooshima A, Hashizume N, et al. Effect of lysyl hydroxylase inhibitor, minoxidil, on ultrastructure and behavior of cultured rabbit subconjunctival fibroblasts. Graefes Arch Clin Exp Ophthalmol 1995;233: 347-353.

34 Saika S, Kono-Saika S, Tanaka T, et al. Smad3 is required for dedifferentiation of retinal pigment epithelium following retinal detachment in mice. Lab Invest 2004;84:1245-1258.

35 Saika S, Ikeda K, Yamanaka O, et al. Transient adenoviral gene transfer of Smad7 prevents injuryinduced epithelial-mesenchymal transition of lens epithelium in mice. Lab Invest 2004;84: 1259-1270.

36 Saika S, Ikeda K, Yamanaka O, et al. Expression of Smad7 in mouse eyes accelerates healing of corneal tissue following exposure to alkali. Am J Pathol 2005; 166:1405-1418.
37 Zhan Y, Kim S, Izumi Y, et al. Role of JNK, p38, and ERK in platelet-derived growth factor-induced vascular proliferation, migration, and gene expression. Arterioscler Thromb Vasc Biol 2003;23:795-801.

38 Furukawa F, Matsuzaki K, Mori S, et al. p38 MAPK mediates fibrogenic signal through Smad3 phosphorylation in rat myofibroblasts. Hepatology 2003;38: 879-889.

39 Yoo J, Ghiassi M, Jirmanova L, et al. Transforming growth factor-beta-induced apoptosis is mediated by Smad-dependent expression of GADD45b through p38 activation. J Biol Chem 2003;278:43001-43007.

40 Watanabe H, de Caestecker MP, Yamada Y. Transcriptional cross-talk between Smad, ERK1/2, and p38 mitogen-activated protein kinase pathways regulates transforming growth factor- $\beta$-induced aggrecan gene expression in chondrogenic ATDC5 cells. J Biol Chem 2001;276:14466-14473.

41 Hanafusa H, Ninomiya-Tsuji J, Masuyama N, et al. Involvement of the p38 mitogen-activated protein kinase pathway in transforming growth factor- $\beta$-induced gene expression. J Biol Chem 1999;274:2716127167.

42 Sano Y, Harada J, Tashiro S, et al. ATF-2 is a common nuclear target of Smad and TAK1 pathways in transforming growth factor- $\beta$ signaling. J Biol Chem 1999;274:8949-8957.

43 Tsukada S, Westwick JK, Ikejima K, et al. SMAD and p38 signaling pathways independently regulate a1(I) collagen gene expression in unstimulated and transforming growth factor-b-stimulated hepatic stellate cells. J Biol Chem 2005;280:10055-10064.

$44 \mathrm{Fu}$ Y, O’Connor LM, Shepherd TG, et al. The p38 MAPK inhibitor, PD169316, inhibits transforming growth factor beta-induced Smad signaling in human ovarian cancer cells. Biochem Biophys Res Commun 2003;310:391-397.

45 Petritsch C, Beug H, Balmain A, et al. TGF- $\beta$ inhibits p70 S6 kinase via protein phosphatase $2 \mathrm{~A}$ to induce G(1) arrest. Genes Dev 2000;14:3093-3101.

46 Verrecchia F, Chu ML, Mauviel A. Identification of novel TGF- $\beta /$ Smad gene targets in dermal fibroblasts using a combined cDNA microarray/promoter transactivation approach. J Biol Chem 2001;276:17058-17062.

47 Hocevar BA, Brown TL, Howe PH. TGF- $\beta$ induces fibronectin synthesis through a c-Jun N-terminal kinase-dependent, Smad4-independent pathway. EMBO J 1999;18:1345-1356.

48 Takekawa M, Tatebayashi K, Itoh F, et al. Smaddependent GADD45b expression mediates delayed activation of p38 MAP kinase by TGF- $\beta$. EMBO J 2002;21:6473-6482.

49 Ashcroft GS, Yang X, Glick AB, et al. Mice lacking Smad3 show accelerated wound healing and an impaired local inflammatory response. Nat Cell Biol 1999;1:260-266.

50 Roberts AB, Russo A, Felici A, et al. Smad3: a key player in pathogenetic mechanisms dependent on TGF- $\beta$. Ann NY Acad Sci 2003;995:1-10.

51 Mitsuhiro MR, Eguchi S, Yamashita H. Regulation mechanisms of retinal pigment epithelial cell migration by the TGF-beta superfamily. Acta Ophthalmol Scand. 2003;81:630-638. 